\title{
Correction to: Knowledge Transfer and Creation Systems: Perspectives on Corporate Socialization Mechanisms and Human Resource Management
}

\author{
Tamiko Kasahara
}

\section{Correction to:}

Chapter 10 in: J. Cantwell and T. Hayashi (eds.), Paradigm Shift in Technologies and Innovation Systems, https://doi.org/10.1007/978-981-32-9350-2_10

In the original version of this chapter, the following belated correction has been incorporated in Table 10.1 of Chapter 10:

2016 Present-CTP was nominated for the best company award from Great Place to Work ${ }^{\circledR}$ Institute

2017 • Present-CTP was nominated for the best company award from Great Place to Work $^{\circledR}$ Institute

2018 Present-CTP was nominated for the best company award from Great Place to Work ${ }^{\circledR}$ Institute

The erratum chapter has been updated with the change. 